\title{
Peran Profitabilitas dan Good Corporate Governance dalam Memediasi Pengaruh Struktur Modal Terhadap Nilai Perusahaan
}

(Studi Empiris Pada Perusahaan Manufaktur sektor Makanan dan Minuman di Bursa Efek Indonesia Tahun 2016-2018)

\author{
Imam Mujahidin, Luhgiatno, Eman Sukanto \\ Sekolah Tinggi Ilmu Ekonomi Pelita Nusantara \\ imammujahidin1998@gmail.com
}

\begin{abstract}
Abstrak
Penelitian ini mengenai nilai perusahaan manufaktur sector makanan dan minuman di Bursa Efek Indonesia tahun 2016 sampai dengan 2018. Tujuannya adalah menganalisis pengaruh Profitabilitas dan Good Corporate Governance dalam memediasi pengaruh Struktur Modal terhadap nilai perusahaan. Metode analisis data menggunakan regresi berganda dan uji sobel utuk menguji hipotesis. Populasi dalam penelitan ini adalah perusahaan manufaktur sector makanan dan minuman yang terdaftar di Bursa Efek Indonesia tahun 2016 sampai sengan 2018. Sampel dalam penelitian ini terpilih melalui purposive sampling, sehingga diperoleh sampel sebanyak 42 perusahaan.

Hasil penelitian ini adalah struktur modal berpengaruh negatif dan signifikan terhadap profitabilitas. Struktur modal berpengaruh Positif Dan signifikan terhadap Good Corporate Governance (GCG). Struktur modal berpengaruh positif dan signifikan terhadap Nilai Perusahaan. Profitabilitas berpengaruh positif dan signifikan terhadap Nilai Perusahaan. Good Corporate Governance (GCG) berpengaruh positif tidak signifikan terhadap Nilai Perusahaan. Profitabilitas tidak dapat memediasi hubungan struktur modal terhadap nilai perusahaan. Good Corporate Governance (GCG) tidak dapat memediasi hubungan struktur modal terhadap nilai perusahaan.
\end{abstract}

Kata Kunci : Profitabilitas, Good Corporate Governance, Struktur Modal, Nilai Perusahaan

\section{Abstract}

This study is about the value of the food and beverage sector manufacturing companies in the Indonesia Stock Exchange from 2013 to 2016. The objective is to analyze the effect of Profitability and Good Corporate Governance in mediating the effect of capital structure on firm value.

Methods of data analysis using multiple regression and single test to test the hypothesis. The population in this research are food and beverage sector manufacturing companies listed on the Indonesia Stock Exchange from 2016 to 2018. The sample in this study was selected through purposive sampling, so that a sample of 42 companies was obtained.

The result of this research is that capital structure has a negative and significant effect on profitability. Capital structure has a positive and significant effect on Good Corporate Governance (GCG). Capital structure has a positive and significant effect on Firm Value. Profitability has a positive and significant effect on Firm Value. Good Corporate Governance (GCG) has a positive and insignificant effect on Company Value. Profitability cannot mediate the relationship between capital structure and firm value. Good Corporate Governance $(G C G)$ cannot mediate the relationship between capital structure and firm value.

Kata Kunci : Profitability, Good Corporate Governance, Capital Structure, Company Value 


\section{Pendahuluan \\ Latar Belakang}

Tujuan utama perusahaan yang telah go public adalah meningkatkan kemakmuran para pemegang saham melalui peningkatan nilai perusahaan. Nilai perusahaan menggambarkan kinerja perusahaan yang dapat mempengaruhi persepsi investor terhadap perusahaan. Martono dan Harjito (2013) mengatakan bahwa nilai perusahaan sangat penting karena dengan meningkatnya nilai perusahaan berarti meningkat pula kemakmuran pemilik perusahaan atau pemegang saham perusahaan.Peningkatan harga saham mempengaruhi nilai perusahaan secara maksimum sehingga memberikan kemakmuran bagi pemegang saham ketika harga saham tinggi, maka kemakmuran pemegang sahamnya semakin tinggi. Enterprise Value (EV) atau firm value (nilai perusahaan) adalah suatu indikator bagi pasar dalam memberikan peniliaian secara keseluruhan terhadap perusahaan (Salvatore 2011:10). Peningkatan nilai perusahaan yang tinggi merupakan tujuan jangka panjang yang seharusnya dicapai perusahaan yang akan tercermin dari harga pasar sahamnya karena penilaian investor terhadap perusahaan dapat diamati melalui pergerakan harga saham perusahaan yang ditransaksikan di bursa untuk perusahaan yang sudah go public.

Penerapan good corporate governance diyakini mampu menciptakan fondasi dan eksistensi yang kokoh dan kondusif dalam memelihara siklus kehidupan suatu perusahaan dengan baik. Para investor akan selalu meninjau kinerja perusahaan secara aktif karena mereka berkeyakinan bahwa penerapan good corporate governance dapat memberikan dampak keuntungan yang positif bagi mereka. Semakin baik perusahaan dalam menerapkan GCG, maka akan berdampak pada kinerja keuangan yang mengakibatkan meningkatnya nilai perusahaan (Mardiasari, 2012).

Komite Cadbury dalam Surya dan Ivan (2006) mnatakan corporate governance adalah sistem yang mengarahkan dan mengendalikan perusahaan dengan tujuan agar mencapai keseimbangan antara kekuatan kewenangan yang diperlukan oleh perusahaan untuk menjamin kelangsungan eksistensinya dan pertanggung jawaban kepada stakeholders. GCG merupakan suatu hal yang penting untuk mewujudkan peningkatan kinerja perusahaan melalui monitoring kinerja manajemen dan menjamin akuntabilitas manajemen terhadap para pemegang saham (Nugroho, 2014)

Pembentukan dewan komisaris merupakan salah satu mekanisme yang digunakan untuk memonitor kinerja manajer. Surat Keputusan Direksi PT. Bursa Efek Jakarta BEJ Nomor: Kep-315/BEJ/06-2000 mengharuskan perusahaan yang terdaftar di bursa efek untuk memiliki dewan komisaris yang memonitor perusahaan agar tercipta Good Corporate Governance di Indonesia. Secara hukum dewan komisaris bertugas melakukan pengawasan dan memberikan nasehat kepada direksi. Dalam melakukan pemantauan terhadap direksi, dewan komisaris memastikan bahwa direksi telah menindaklanjuti temuan audit dan rekomendasi dari satuan kerja audit intern perusahaan (SKAI), auditor eksternal, hasil pengawasan perusahaan dan/atau hasil pengawasan otoritas lain. Dewan Komisaris dalam melaksanakan tugasnya harus mampu mengawasi dipenuhinya kepentingan semua stakeholders berdasarkan azas kesetaraan, serta mengarahkan, memantau, dan mengevaluasi pelaksanaan kebijakan strategis perusahaan (Andri Veno, 2015).

Terdapat teori-teori struktur modal yang menjelaskan bagaimana pengaruh struktur modal terhadap nilai perusahaan. Nilai perusahaan tidak dipengaruhi oleh darimana suatu perusahaan mendanai kegiatan operasionalnya, ini terdapat dalam teori struktur modal oleh Modigliani dan Merton Miller (MM) (Brigham dan Houston, 2011). Trade off theory menjelaskan pengaruh yang berbeda bawha apabila posisi struktur modal berada di bawah titik optimal maka setiap penambahan utang dapat meningkatkan nilai perusahaan, namun sebaliknya apabila target struktur modal telah tercapai maka setiap pertambahan utang dapat menurunkan nilai perusahaan (Badjuri,2011). 
Kombinasi antara utang dan ekuitas mendapatkan sturuktur modal yang paling optimal yang dapat meningkatkan harga saham suatu perusahaan Hermuningsih (2012). Struktur modal dalam penelitian ini diukur dengan debt to equity ratio (DER) dimana rasio ini menunjukkan struktur modal dari total pinjaman perusahaan terdapat modal yang dimiliki perusahaan, maka dari itu utang juga dapat merupakan unsur dari struktur modal perusahaan itu sendiri.

Seorang investor pasti mengharapkan profit dari investasi yang telah dilakukannya, maka rasio pertumbuhan profitabilitas perusahaan juga menjadi hal yang sangat diperhatikan oleh investor. Nofrita (2013) profitabilitas merupakan kemampuan perusahaan memperoleh laba dalam hubungannya dengan penjualan, total aktiva atau dengan modal (ekuitas). Gitman (2016) Rasio utama dalam seluruh laporan keuangan untuk mendapatkan keuntungan yang akan digunakan untuk mengukur keefektifan operasi perusahaan sehingga menghasilkan keuntungan pada perusahaan. Profitabilitas merupakan hasil bersih dari sejumlah kebijakan dan keputusan peusahaan. (James dan Wachowicz, 2016) mengemukakan profitabilitas dalam hubungannya dengan penjualan terdiri atas margin laba kotor (gross profit margin) dan margin laba bersih (net profit margin). Profitabilitas dalam hubungannya dengan investasi terdiri atas tingkat pengembalian atas aktiva (retrun on total assets) dan tingkat pengembalian atas ekuitas (retrun on equity).Rasio profitabilitas yang semakin tinggi akan berdampak pada meningkatnya nilai perusahaan yang nantinya akan menarik minat para investor untuk menanamkan sahamnya di perusahaan tersebut guna memperoleh return tertentu. Nilai return yang dihasilkan dapat menggambarkan seberapa baik nilai perusahaan di mata investor.

\section{Rumusan Masalah}

1. Apakah struktur modal (DER) berpengaruh terhadap profitabilitas (ROA) ?

2. Apakah struktur modal (DER) berpengaruh terhadap good corporate governance (GCG) ?

3. Apakah struktur modal (DER) berpengaruh terhadap nilai perusahaan (PBV)?

4. Apakah profitabilitas (ROA) berpengaruh terhadap nilai perusahaan (PBV) ?

5. Apakah good corporate governance (GCG) berpengaruh terhadap nilai perusahaan (PBV) ?

6. Apakah struktur modal (DER) melalui profitabilitas (ROA) berpengaruh terhadap nilai perusahaan (PBV)?

7. Apakah struktur modal (DER) melalui good corporate governance (GCG) berpengaruh terhadap nilai perusahaan (PBV) ?

\section{Tinjauan Pustaka}

Signalling Theory

Brigham dan Houston (2011), signal adalah suatu tindakan yang diambil perusahaan untuk memberi petunjuk bagi Investor tentang bagaimana manajemen memandang prospek perusahaan. Teori signal menunjukkan adanya asimetri informasi antara manajemen perusahaan dan pihak yang memiliki kepentingan terhadap informasi tersebut. Menurut Jamaan dalam Spence (1973) signalling theory menjelaskan tentang bagaimana seharusnya sebuah perusahaan memberikan sinyal kepada para pengguna laporan keuangan. Sinyal ini berupa informasi mengenai apa yang telah dilakukan oleh manajemen untuk memenuhi keinginan pemilik. Signalling theory menyatakan bahwa:

a. Pengeluaran investasi memberikan sinyal positif tentang pertumbuhan perusahaan dimasa yang akan datang, sehingga meningkatkan harga saham sebagai ndikator nilai perusahaan (Hasnawati, 2005).

b. Peningkatan utang dapat diartikan pihak luar tentang kemampuan perusahaan untuk membayar kewajibannya dimasa yang akan datang atau resiko bisnis yang rendah, 
sehingga penambahan utang akan memberikan sinyal positif (Brigham dan Houston, 2011).

c. Kebijakan deviden sering dianggap sebagai sinyal bagi para investor dalam menilai baik buruknya suatu perusahaan, hal ini disebabkan karena kebijakan deviden dapat memberikan pengaruh terhadap harga saham perusahaan.

\section{Pecking Order Theory}

Pecking order theory teori ini dikemukakan oleh Myers dan Majluf (1984) dalam Saidi (2004) menyatakan bahwa perusahaan menyukai internal financing (pendanaan operasi perusahaan yang diambil dari laba ditahan). Urutan penggunaan sumber dana dengan mengacu pada pecking order theory menurut (Kaaro,2003) dalam (Saidi, 2004) adalah : a). Perusahaan cenderung menggunakan internal financing (pendanaan operasi perusahaan yang diambil dari laba ditahan). b). Apabila pendanaan eksternal di butuhkan perusahaan akan menerbitkan hutang (debt) terlebih dahulu, apabila dengan hutang masih belum tercukupi perusahaan akan menerbitkan saham baru. Penggunaan dana internal lebih disukai karena memungkinkan perusahaan untuk tidak perlu membuka diri lagi dari sorotan pemodal luar. Kalau bisa memperoleh sumber dana yang dibutuhkan tanpa memperoleh sorotan dan publisitas publik sebagai akibat penerbitan saham baru.

\section{Trade-off Theory}

Teori struktur modal pertama kali dipelopori oleh Modigliani dan Miller tahun 1958. Salah satu asumsi dalam pasar sempurna adalah tidak ada pajak. Proporsi MM adalah "jika tidak ada pajak, struktur modal tidak mempengaruhi nilai perusahaan”. Dengan kata lain, jika tidak ada pajak, maka struktur modal adalah irrelevance. Proporsi ini dibuktikan dengan menggunakan arbitrase. Dalam perkembangannya, Modigliani-Miller memasukkan unsur pajak, sehingga struktur modal menjadi relevan, karena bunga yang dibayarkan akibat menggunakan utang dapat mengurangi penghasilan kena pajak (tax deductible). Nilai perusahaan akan maksimum, jika perusahaan menggunakan $100 \%$ utang dan semakin banyak utang adalah semakin baik, fenomena ini disebut corner optimum leverage decision. Dalam praktek penggunaan utang $100 \%$ sulit dijumpai dan hal ini ditentang oleh trade-off theory. Kenyataannya, semakin besar utang semakin tinggi beban yang harus ditanggung perusahaan, karena adanya agency cost, biaya kebangkrutan, keengganan kreditur untuk memberi utang besar, dan sebagainya

\section{Struktur Modal}

Strukur modal merupakan perbandingan total hutang yang dimiliki perusahaan terhadap total ekuitas perusahaan. Struktur modal diukur dengan Debt to Equity Ratio (DER). Debt to Equity Ratio adalah suatu upaya memperlihatkan dalam format lain. proporsi relative diklaim pemberi pinjaman terhadap hak kepemilikan dan digunakan sebagai ukuran peranan hutang (Mamduh, 2014)

$$
\mathrm{DER}=\frac{\text { Total Debt }}{\text { Total Equity }} \quad \mathrm{X} 100 \%
$$

\section{Nilai Perusahaan}

Nilai perusahaan adalah persepsi investor terhadap tingkat keberhasilan perusahaan, tidak hanya saat ini namun juga pada prospek perusahaan di masa depan. Nilai perusahaan dapat diukur dengan rasio harga saham terhadap nilai buku perusahaan atau Price Book Value (PBV). Pada penelitian ini nilai perusahaan diukur dengan PBV pada akhir tahun, yaitu rasio harga saham terhadap nilai buku perusahaan atau price book value (PBV), menunjukkan 
tingkat kemampuan perusahaan menciptakan nilai relative terhadap jumlah modal yang diinvestasikan.

Nilai perusahaan dipandang sebagai sesuatu yang sangat penting karena dengan nilai perusahaan yang tinggi, maka akan diikuti dengan tingginya kemakmuran pemegang saham. Semakin tinggi harga saham, maka semakin tinggi nilai perusahaan tersebut, semakintinggi nilai perusahaan maka semakin tingi pula kemakmuran para pemilik saham (Surya dan Yustiavandana, 2007)

PBV $=\frac{\text { Harga Pasar Persaham }}{\text { Nilai Buku }} \times 100 \%$

\section{Profitabilitas}

Profitabilitas merupakan gambaran dari kinerja manajemen dalam mengelola perusahaan. Return On Asset adalah perbandingan antara laba bersih sesudah pajak dengan total aset yang dipergunakan untuk menghasilkan laba dan dinyatakan dalam persentase. Dalam penelitian ini Return On Asset (ROA) diukur dengan membagi laba bersih sesudah pajak dengan total aset (Sunyoto, 2013).

Rasio profitabilitas dapat diukur dengan dua pendekatan, yaitu pendekatan penjualan dan pendekatan investasi (Martono, 2013). Rasio profitabilitas yang berhubungan dengan penjualan adalah (Kasmir, 2010) :

a. Gross Profit Margin (GPM)

Rasio ini merupakan persentase laba kotor dibandingakan dengan penjualan, digunakan untuk meengukur kemampuan produksi perusahaan secara efisien.

b. Net Profit Margin (NPM)

Rasio ini mengukur laba bersih setelah pajak terhadap penjualan. semakin tinggi NPF semakin baik operasi suatu perusahaan.

Sedangkan rasio profitabilitas yang berhubungan dengan investasi adalah (Besley dan Brigham, 2008) :

\section{Return On Equity (ROE)}

Rasio ini dihitung dengan membagi laba bersaih dengan total aset. Rasio ini menunjukkan seberapa banyak laba bersih yang bisa diperoleh dari total kekayaan yang dimilki perusahaan.

2. Basic Earning Power Ratio (BEPR)

Rasio ini dihitung dengan membagi laba sebelum bunga dan pajak. (earning before interest and taxes-EBIT) dengan total aset. Rasio ini menunjukkan kemampuan menghasilkan laba dari aset perusahaan sebelum pengaruh bunga serta pajak.

Sehingga secara matematis dapat dituliskan:

Laba Bersih Sesudah Pajak

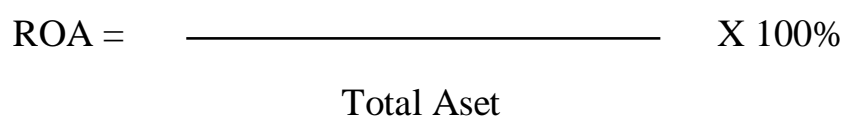

\section{Good Corporate Governance}

Good Corporate Governance adalah seperangkat peraturan yang mengatur hubungan antara pemegang saham, pengurus (pengelola) perusahaan, pihak kreditur, pemerintah, karyawan serta pemegang kepentingan internal dan eksternal lainnya yang berkaitan dengan hak-hak dan kewajiban mereka atau dengan kata lain suatu sistem yang megatur dan mengendalikan perusahaan (FCGI (2001) dalam Agoes dan Ardana 2009). Pengukuran variable Good Corporate Governance ini dengan menggunakan Proporsi Dewan Komisaris 
Independen. Komisaris independent adalah anggota dewan komisaris yang tidak berafiliasi dengan manajemen, anggota dewan komisaris lainnya dan pemegang saham pengendali, bebas dari hubungan bisnis atau hubungan lainnya yang dapat mempengaruhi kenampuan untuk bertindak independent atau bertindak semata-mata sesuai kepentingan perusahaan (Wardhani (2008) dalam Agoes dan Ardana. 2009).

Organization of Economic Cooperation and Development(OECD dalam Agus dan Ardana, 2009) menyatakan prinsip GCG terdiri dari empat yaitu :

a. Fairness (keadilan)

Perlakuan yang sama terhadap para pemegang saham, terutama pada pemegang saham minoritas dan pemegang saham asing, dengan keterbukaan informasi yang penting serta melarang pembagian untuk pihak sendiri dan perdagangan saham oleh orang dalam (Insider trading).

b. Transparency (Transparansi)

Hak-hak para pemegang saham yang harus diberi informasi dengan benar dan tepat pada waktunya mengenai perusahaan. Mereka dapat berpartisipasi dalam pengambilan keputusan mengenai perubahan-perubahn mendasar dalam perusahaan dan turut serta memperoleh bagian keuntungan perusahaan

c. Accountability (Akuntabilitas)

Merupakan bentuk tanggung jawab manajemen dalam bentuk pengawasan yang efektif berdasarkan balance of power antara manajer, pemegang saham, dewan komisaris, dan auditor.

d. Responsibility (Tanggung Jawab)

Peran pemegang saham harus diakui sebagaimana ditetapkan oleh hukum dan kerja sama yang aktif antara perusahaan serta pemegang kepentingan dalam menciptakan kesejahteraan dan perusahaan yang sehat dari aspek keuangan. Hal ini sebagai bentuk tanggung jawab perusahaan sebagai anggota masyarakat yang juga memperhatikan kondisi masyarakat-masyarakat disekitarnya. berikut:

Proporsi Dewan Komisaris Independen diberi simbol DKI yang diformulasikan sebagai

Jumlah Anggota Komisaris Independen

$\mathrm{DKI}=$ X $100 \%$

Jumlah Seluruh Anggota Komisaris

\section{Kerangka Pemikiran Dan Hipotesis \\ Hubungan Struktur Modal (DER) Terhadap Profitabilitas (ROA)}

Myers dan Majluf (1984) dalam Saidi (2004) menyatakan bahwa perusahaan menyukai internal financing (pendanaan dari hasil operasi perusahaan berwujud laba ditahan). Uruturutan penggunaan sumber pendanaan dengan mengacu pada pecking order theory menurut (Kaaro, 2003) dalam (Saidi, 2004) adalah: a. Perusahaan cenderung menggunakan internal financing yang berasal dari laba ditahan perusahaan. b. Jika pendanaan eksternal dibutuhkan, perusahaan akan menerbitkan hutang (debt) terlebih dahulu, baru jika penggunaan hutang masih kurang mencukupi perusahaan akan menerbitkan saham baru. Dana internal lebih disukai karena memungkinkan perusahaan untuk tidak perlu "membuka diri lagi" dari sorotan pemodal luar. Kalau bias memperoleh sumber dana yang diperlukan tanpa memperoleh "sorotan dan publisitas publik" sebagai akibat penerbitan saham baru. Dana eksternal lebih disukai dalam bentuk hutang daripada modal sendiri.

Konsep struktur modal adalah perbandingan jumlah hutang jangka Panjang dengan modal sendiri, Pemilik sebuah perusahaan mungkin dapat mempergunakan hutang yang berjumlah relative besar untuk membatasi manajernya. Rasio hutang yang tinggi akan 
meningkatkan ancaman kebangkrutan untuk menjadi lebih berhati-hati dan tidak menghambur-hamburkan uang para pemegang saham. Kebanyakan pengambil alihan perusahaan dan pembelian melalui hutang dirancang untuk meningkatkan efisiensi dengan mengurangi arus kas bebas yang tersedia bagi para manajer (Bringham dan Houston, 2004), Pembelanjaan yang dilakukan oleh manajemen keuangan akan membentuk struktur keuangan yang dapat menunjukkan komposisi perbandingan sumber dana perusahaan dalam membiayai operasional perusahaan. Bagi setiap perusahaan, keputusan dalam pemilihan sumber dana merupakan hal penting sebab hal tersebut akan mempengaruhi struktur keuangan perusahaan, yang akhirnya akan mempengaruhi profitabilitas.

Sumber dana perusahaan dicerminkan oleh modal asing dan modal sendiri yang diukur dengan debt to equity ratio (DER). Jika DER semakin tinggi, maka kemampuan perusahaan untuk mendapatkan profitabilitas akan semakin tinggi, sehingga DER mempunyai hubungan positif dengan profitabilitas. Beberapa peneliti antara lain: Ahmad, et al (2018) dan Dewa (2011) mengatakan bahwa struktur modal berpengaruh positif terhadap profitabilitas. Jikas truktur modal meningkat, maka profitabilitas akan meningkat.

\section{Hubungan Struktur Modal (DER) Terhadap Good Corporate Governance (GCG)}

Struktur modal diperlukan untuk meningkatkan nilai perusahaan karena penetapan struktur modal dalam kebijakan pendanaan perusahaan menentukan pertumbuhan perusahaan. Prinsip manajemen perusahaan baik dalam memperoleh maupun menggunakan dana harus didasarkan pada efisiensi dan efektifitas. Efisiensi penggunaan dana berarti bahwa berapapun dana yang ditanamkan dalam aktiva harus dapat digunakan seefisien mungkin untuk menghasilkan tingkat keuntungan investasi yang maksimal. Oleh karenaitu, pengalokasian dana harus didasarkan pada perencanaan yang tepat sehingga dana yang menganggur menjadi kecil. Efisiensi penggunaan dana secara langsung dan tidak langsung akan menentukan besar kecilnya keuntungan yang dihasilkan dari investasi (Eli, 2008).

Corporate governance sebagai proses dan struktur yang diterapkan dalam menjalankan perusahaan, dengan tujuan utama meningkatkan nilai pemegang saham dalam jangka panjang, dengan tetap memperhatikan kepentingan stakeholders yang lain (IICG, 2007). Good corporate governance berperan mengendalikan manajer perusahaan dalam mengambil keputusan investasi, penggunaan laba dan kebijakan deviden sebagai upaya untuk meningkatkan nilai perusahaan. Penelitian tentang struktur modal terhadap good corporate governance Ahmad, et al (2018) dan Sugeng (2009) menyatakan bahwa struktur modal berpengaruh positif signifikan terhadap good corporate governance Jika modal meningkat maka good corporate governance meningkat.

\section{Hubungan Struktur Modal (DER) Terhadap Nilai Perusahaan (PBV)}

Signaling theor $y$ menjelaskan bahwa jika posisi struktur modal berada di bawah titik optimal maka setiap penambahan hutang akan meningkatkan nilai perusahaan. Dan sebaliknya, jika posisi struktur modal berada di atas titik optimal maka setiap penambahan hutang akan menurunkan nilai perusahaan. Beberapa penelitian terdahulu Ni Kadek dan I Gede (2016) dan Dewa (2011) Mengatakan bahwa sturktur modal berpengaruh positif signifikan. Jika struktur modal mengalami peningkatan maka nilai perusahaan akan meningkat.

\section{Hubungan Profitabilitas (ROA) Terhadap Nilai Perusahaan (PBV)}

Berdasarkan konsep signaling theory semakin baik pertumbuhan profitabilitas berarti prospek perusahaan di masa depan dinilai semakin baik juga, artinya semakin baik pula nilai 
perusahaan di mata investor. Apabila kemampuan perusahaan untuk menghasilkan laba meningkat, maka harga saham juga akan meningkat (Husnan 2001). Harga saham yang meningkat mencerminkan nilai perusahaan yang baik bagi investor. Mardiyati, et al (2012), Nur dan Puji (2018) menyatakan bahwa nilai perusahaan berpengaruh positif dan signifikan terhadap profitabilitas. Semakin tinggi profitabilitas perusahaan semakin tinggi pula nilai perusahaan di mata investor.

\section{Hubungan Good Corporate Governance (GCG) Terhadap Nilai Perusahaan (PBV)}

Penelitian ini menghubungkan good corporate governace terhadap nilai perusahaan berdasarkan pendekatan konsep signaling theory. Teori sinyal membahas mengenai dorongan perusahaan untuk memberikan informasi kepada pihak eksternal. Berdasarkan konsep signaling theory bahwa dengan konsep tata kelola yang baik (good corporate governance) maka, akan dapat memberikan sinyal positif di mata investor terhadap perusahaan. Reny (2012), dan Salsabila dan Saifi (2017) menyatakan bahwa good corporate governance berpengaruh positif signifikan terhadap nilai perusahaan. Semakin baik tata kelola perusahaan (good corporate governance) semakin tinggi pula nilai perusahaan di mata investor.

\section{Hubungan Struktur Modal Terhadap Nilai perusahaan Dengan Profitabilitas (ROA) sebagai Variabel Intervening}

Struktur modal mempengaruhi kemampuan perusahan dalam menghasilkan laba (Sartono, 2001). Mamduh (2014) menjelaskan bahwa nilai akhir saham biasa sebagian bergantung pada tingkat pengembalian yang diharapakan pemegang saham (investor) dalam bentuk deviden tunai. Dengan meminimumkan biaya modal maka perusahaan dapat memaksimumkan arus kas deviden sebagai laba yang dihasilkan perusahaan. Penggunaan hutang bias menurunkan biaya modal perusahaan dengan meningkatkan laba perusahaan Profitabilitas mengukur tingkat kemampuan perusahaan dalam menghasilkan laba, sedangkan rasio profitabilitas secara teoritis adalah pengembalian atas asset. Rasio ini digunakan oleh manajer keuangan dalam meningkatkan profitabilitas perusahaan. Laba yang tinggi memberikan indikasi prospek perusahaan yang baik sehingga dapat mendorong investor untuk meningkatkan permintan saham. Berdasarkan pembahasan di atas yang menunjukkan bahwa struktur modal mempengaruhi profitabilitas dan profitabilitas mempengaruhi nilai perusahaan (Shaw, 2003).

\section{Hubungan Struktur Modal Terhadap Nilai perusahaan Dengan Good Corporate Governance (GCG) sebagai Variabel Intervening}

Dalam konsep struktur modal, struktur modal adalah perbandingan antara total hutang dengan ekuitas (debt to equity ratio). DER mencerminkan kemampuan perusahaan untuk membayar atau memenuhi kewajibannya dengan modal sendiri. Semakin besar nilai DER manunjukkan bahwa semakin besar struktur modal yang berasal dari utang digunakan untuk mendanai ekuitas yang ada (Milanti, 2015).

Teori struktur modal menjelaskan apakah ada pengaruh perubahan struktur modal terhadap nilai perusahaan, apabila keputusan investasi dan kebijakan deviden dipegang konstan. Dengan kata lain, seandainya perusahaan mengganti sebagai modal sendiri dengan hutang (atau sebaliknya) apakah harga saham akan berubah, apabila perusahaan tidak merubah keputusan-keputusan keuangan lainnya. Jika perubahan struktur modal tidak merubah nilai perusahaan, berarti bahwa tidak ada struktur modal yang terbaik. Tetapi jika dengan mengubah struktur modal ternyata nilai perusahaan berubah, maka akan diperoleh struktur modal yang terbaik. Struktur modal yang dapat memaksimumkan nilai perusahaan atau harga saham adalah struktur modal yang terbaik (Husnan, 2000). 
Siallagan dan Machfoedz (2006) mengemukakan bahwa corporate governance merupakan suatu sistem yang mengatur dan mengendalikan perusahaan yang diharapkan dapat memberikan dan meningkatkan nilai perusahaan kepada para pemegang saham. Dengan demikian penerapan good corporate governance dipercaya dapat meningkatkan nilai perusahaan. corporate governance yang efektif dalam jangka Panjang akan dapat meningkatkan kinerja perusahaan dan menguntungkan para pemegang saham.

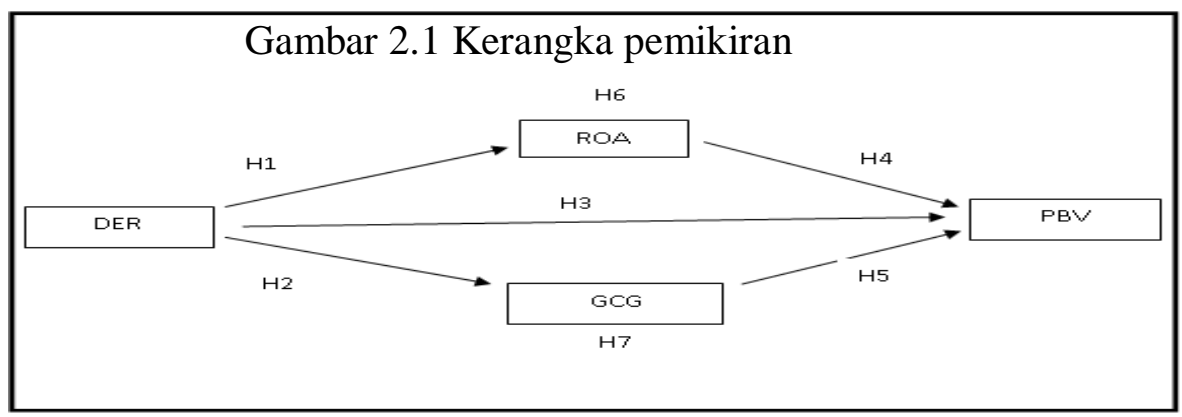

\section{Metodologi Penelitian \\ Populasi dan Sampel}

Populasi yang digunakan dalam penelitian ini adalah perusahaan manufaktur sector makanan dan minuman yang terdaftar di BEI dalam periode 2016 - 2018.

1. Perusahaan Manufaktur sector makanan dan minuman yang tercatat di Bursa Efek Indonesia (BEI) yang menerbitkan laporan tahunan (annual report) 2016-2018 secara berturut-turut.

2. Perusahaan Manufaktur sector makanan dan minuman yang tercatat di Bursa Efek Indonesia (BEI) yang memiliki seluruh variable yang diteliti selama tahun 2016-2018.

\section{Jenis dan Sumber Data}

Data yang diperlukan untuk mendukung analisis dan pengujian hipotesis adalah data sekunder. Sugiyono (2010) menyatakan bahwa data sekunder adalah sumber yang tidak langsung memberikan data kepada pengumpul data berupa annual report. Dalam penelitian ini data sekunder yang digunakan adalah data yang disediakan perusahaan yang Go Public di bursa efek Indonesia yang berasal dari www.idx.co.id dan PIPM Semarang.

\section{Hasil Dan Pembahasan}

\section{Analisis Statistik Deskriptif}

Dari hasil pengujian statistik deskriptif atas satu variabel independen, dua variabel intervening, dan satu variabel dependen, maka diperoleh hasil seperti berikut ini

1. Rata-rata Price Book Value (PBV) yang dijadikan sample dalam penelitian ini adalah sebesar 5,4188 artinya Nilai Perusahaan yang diukur dengan harga pasar persaham dibagi book value pada perusahaan manufaktur sector makanan dan minuman adalah sebesar 5,4188. Nilai minimum PBV adalah sebesar 0,00 dan nilai maksimum dari Nilai perusahaan adalah 47,54. Nilai standar deviasi sebesar 9,79839.

2. Rata-rata Debt to Equity Ratio (DER) yang dijadikan sampel dalam penelitian ini adalah sebesar 0,9817 artinya DER yang diukur dengan total debt dibagi total equity pada perusahaan manufaktur adalah sebesar 0,9817. Nilai minimum DER adalah sebesar 0,17 dan nilai maksimum dari DER adalah sebesar 2,12. Nilai standar deviasi sebesar 0,52565 .

3. Rata-rata Return On Asset (ROA) yang dijadikan sampel dalam penelitian ini adalah sebesar 8,9271 artinya ROA yang diukur dengan laba bersih sesudah pajak dibagi total 
aktiva pada perusahaan manufaktur adalah sebesar 8,9271. Nilai minimum ROA adalah sebesar -9,71 dan nilai maksimum dari ROA adalah sebesar 52,67. Nilai standar deviasi sebesar 11,83056.

4. Rata-rata Good Corporate Governance (GCG) yang dijadikan sample dalam penelitian ini adalah 0,3693 artinya GCG yang diukur dengan Proporsi Dewan Komisaris Independen pada perusahaan manufaktur sector makanan dan minuman adalah sebesar 0,3693. Nilai minimum GCG adalah sebesar 0,30 dan nilai maksimum dari GCG adalah sebesar 0,50. Nilai standar deviasi sebesar 0,08010.

\section{Uji Normalitas}

Uji normalitas yang dipergunakan untuk menguji dalam sebuah model regresi, variable dependen dan variable independent atau keduanya mempunyai distribusi normal atau tidak. Model regresi yang baik adalah distribusi data yang normal atau mendekati normal. Deteksi dengan melihat penyebaran data (titik) pada sumbu diagonal dari grafik. Dasar pengambilan keputusan:

a. Jika data menyebar di sekitar garis diagonal dan mengikuti arah garis diagonal, maka model regresi memenuhi asumsi normalitas.

b. Jika data menyebar jauh dari garis diagonal dan tidak mengikuti arah garis diagonal, maka model regresi tidak memenuhi asumsi normalitas.

Hasil dari output SPSS Normal P-Plot memperlihatkan bahwa distribusi dari titik-titik data Debt to Equity Ratio (DER), Return On Asset (ROA) dan Good Corporate Governance (GCG) menyebar disekitar garis diagonal dan mengikuti arah garis diagonal yang menunjukkan pola distribusi normal, maka dapat dikatakan bahwa data tersebut normal

\section{Uji Multikolinearitas}

Uji Multikolinearitas dimaksudkan untuk mengetahui adanya hubungan yang sempurna antara variable bebas dalam model regresi. Apabila terjadi multikolinearitas maka variable bebas yang berkolinier dapat dihilangkan. Untuk mengetahui ada tidaknya multikolinier menurut perhitungan yang dilakukan model regresi tidak terjadi multikolinearitas apabila:

a. Mempunyai VIF $<10$

b. Mempunyai angka TOLERANCE $>0,1$

Hasil uji melalui Variance Inflation Factor (VIF) pada hasil output SPSS tabel 4.4 Coefficients masing-masing variable independent memiliki VIF tidak lebih dari 10 dan nilai Tolerance tidak kurang dari 0,1, maka dapat dinyatakan model regresi linier berganda terbebas dari asumsi klasik multikolinieritas dan dapat digunakan dalam penelitian.

\section{Uji Heteroskedastisitas}

Uji Heteroskedastisitas digunakan untuk menguji apakah pada model regresi terjadi ketidaksamaan variabel dari residual satu pengamatan ke pengamatan lainnya. Jika variabel dari residual satu pengamatan ke pengamatan lain tetap, maka disebut Homoskedastisitas dan jika berbeda disebut Heteroskedastisitas.. Hasil penelitian yang telah dilakukan maka dapat diperoleh hasil uji heteroskedastisitas sebagai berikut:

data sampel tersebar secara acak dan tidak membentuk suatu pola tertentu. Data tersebar baik berada di atas maupun di bawah angka 0 pada sumbu Y. Hal ini menunjukkan tidak terdapat heteroskedastisitas dalam model regresi, sehingga model regresi layak untuk digunakan.

\section{Uji Autokorelasi}

Uji Autokorelasi digunakan untuk mengetahui ada atau tidaknya penyimpangan asumsi autokorelasi, yaitu korelasi yang terjadi antara residual pada satu pengamatan dengan 
pengamatan lain pada model regresi. Prasyarat yang harus terpenuhi dalam model regresi adalah tidak adanya gejala autokorelasi. Model yang digunakan adalah uji Durbin-Watson. Nilai yang didapat sebesar 1,670. Sedangkan dari tabel DW dengan signifikansi 0,05 dan jumlah data $(\mathrm{n})=42$ serta $\mathrm{k}$ (variable bebas) $=3$ diperoleh nilai dL sebesar 1,357 dan $\mathrm{dU}$ 1,661. Nilai DW 1,670 lebih besar dari batas atas (du) 1,661 dan kurang dari 4 - 1,661 (4 du), maka hipotesis nol diterima, yang berarti tidak ada auto korelasi.

\section{Pengujian H1 dengan Persamaan Regresi Berganda Tahap 1}

Dalam penelitian ini nilai $\mathrm{t}$ tabel adalah $(\mathrm{n}-\mathrm{k})$ dimana $\mathrm{n}=42$ dan $\mathrm{k}=2$ maka $(\mathrm{n}-\mathrm{k}=$ 40), jadi t tabel sebesar 1,683 Berdasarkan perhitungan SPSS diperoleh hasil pada tabel berikut ini: persamaan regresi linear berganda sebagai berikut: ROA $=10,545-1,648$ DER.

Pada persamaan tersebut ditunjukkan pengaruh variabel independen (X) terhadap variabel dependen (Y). Adapun arti dari koefisien regresi tersebut adalah sebagai berikut:

1. Nilai konstanta $\alpha$ sebesar 10,545 mempunyai arti bahwa bila DER $\left(\mathrm{X}_{1}\right)$ dianggap sama dengan nol maka ROA sebesar 10,545.

2. Nilai koefisien regresi DER $\left(\beta_{1}\right)$ sebesar $-1,648$ berarti jika DER $\left(X_{1}\right)$ naik satu satuan, maka ROA akan berkurang sebesar 1,648 dan berlaku sebaliknya. Hal ini menunjukkan DER berpengaruh negative terhadap ROA.

Uji t statistic menghasilkan -0,464 untuk variabel DER lebih kecil dari t tabel $(-0,464<$ 1,683) dengan nilai probabilitas signifikan $0,018<0,05$. Jadi telah terbukti bahwa DER berpengaruh negatif dan signifikan terhadap ROA, dengan demikian $\mathrm{H} 1$ ditolak.

\section{Pengujian H2 dengan Persamaan Regresi Berganda Tahap 2}

Dalam penelitian ini nilai $\mathrm{t}$ tabel adalah $(\mathrm{n}-\mathrm{k})$ dimana $\mathrm{n}=42$ dan $\mathrm{k}=2$ maka $(\mathrm{n}-\mathrm{k}=$ 40), jadi t tabel sebesar 1,683 Berdasarkan perhitungan SPSS diperoleh hasil pada tabel berikut ini: Berdasarkan tabel 4.13 dapat dijelaskan bahwa persamaan regresi linear berganda sebagai berikut: $\mathrm{GCG}=0,324+0,046$ DER

Uji t statistic menghasilkan 1,991 untuk variabel DER lebih besar dari t tabel $(1,991 \geq$ 1,683 ) dengan nilai probabilitas signifikan $0,003<0,05$. Jadi telah terbukti bahwa DER berpengaruh positif dan signifikan terhadap GCG, dengan demikian $\mathrm{H} 2$ diterima

\section{Pengujian H3, H4, dan H5 dengan Persamaan Regresi Berganda Tahap 3}

Dalam penelitian ini nilai $\mathrm{t}$ tabel adalah $(\mathrm{n}-\mathrm{k})$ dimana $\mathrm{n}=42$ dan $\mathrm{k}=4$ maka $(\mathrm{n}-\mathrm{k}=$ 38), jadi t tabel sebesar 1,685 Berdasarkan perhitungan SPSS diperoleh hasil pada tabel berikut ini: Berdasarkan tabel 4.14 dapat dijelaskan bahwa persamaan regresi linear berganda sebagai berikut: PBV = 10,500 - 7,632 DER + 0,646 ROA - 7,192 GCG

Uji t statistic menghasilkan 5,040 untuk variabel DER lebih besar dari t tabel $(5,040 \geq$ 1,685) dengan nilai probabilitas signifikan $0,000<0,05$. Jadi telah terbukti bahwa DER berpengaruh positif dan signifikan terhadap PBV, dengan demikian $\mathrm{H} 3$ diterima.

Uji t statistic menghasilkan 9,378 untuk variabel ROA lebih besar dari t tabel $(9,378 \geq$ 1,685) dengan nilai probabilitas signifikan 0,000 $<0,05$. Jadi telah terbukti bahwa ROA berpengaruh positif dan signifikan terhadap PBV, dengan demikian $\mathrm{H} 4$ diterima.

Uji t statistic menghasilkan 0,676 untuk variabel GCG lebih kecil dari t tabel $(0,676<$ 1,685 ) dengan nilai probabilitas signifikan $0,503 \geq 0,05$. Jadi telah terbukti bahwa GCG berpengaruh positif dan tidak signifikan terhadap PBV, dengan demikian H5 ditolak.

\section{Uji Sobel}

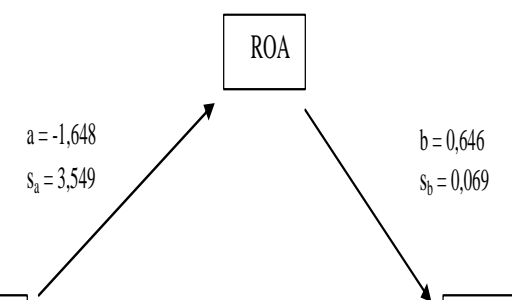




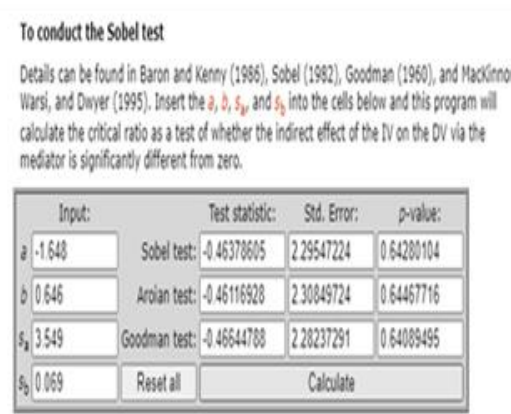

Uji Z sobel test menghasilkan $-0,463$ untuk variabel ROA memediasi DER dengan PBV, lebih kecil dari nilai $Z$ tabel $(-0,463<1,96)$ dengan nilai probabilitas signifikan $0,642 \geq$ 0,05. Jadi telah terbukti bahwa variabel ROA berpengaruh negatif dan tidak signifikan dalam memediasi DER dengan PBV, dengan demikian H6 ditolak.

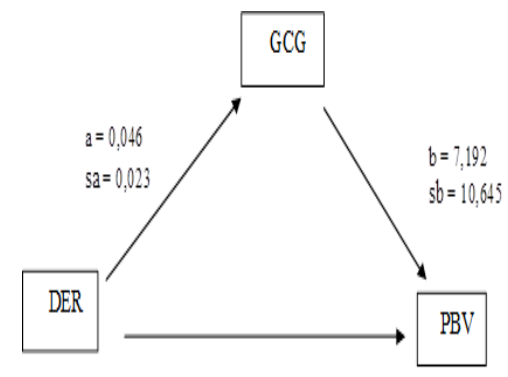

$$
\begin{aligned}
& \text { To conduct the Sobel test } \\
& \text { Detalis can be found in Baron and Kenny (1996), Sobel (1982), Goodman (1960), and Mackinnon, } \\
& \text { Warsi, and Daver (1995), Inserer the a, b, sy and s, into the cels below and this progeram will } \\
& \text { calculate the critical rato as a tess of whether the indrect effect of the IV on the OV via the } \\
& \text { calculate the criteal rato as a test of whedres }
\end{aligned}
$$

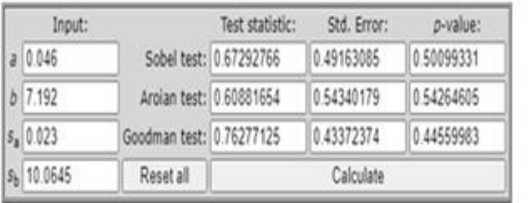

Uji Z sobel test menghasilkan 0,672 untuk variabel DER memediasi GCG dengan PBV, lebih kecil dari nilai $\mathrm{Z}$ tabel $(0,672<1,96)$ yang menghasilkan nilai probabilitas signifikan $0,500 \geq 0,05$. Jadi telah terbukti bahwa variabel GCG berpengaruh positif dan tidak signifikan dalam memediasi DER dengan PBV, dengan demikian H7 ditolak.

\section{Pembahasan}

\section{Pengaruh Debt to Equity Ratio (DER) terhadap Return On Asset (ROA)}

Berdasarkan hasil perhitungan dengan Analisis Regresi Berganda menunjukkan bahwa Debt to Equity (DER) berpengaruh negatif dan signifikan terhadap Return On Asset (ROA) pada perusahaan manufaktur sektor makanan dan minuman yang terdaftar di Bursa Efek Indonesia tahun 2016 sampai dengan tahun 2018. Pengaruh yang negatif dan tidak signifikan ini menunjukkan bahwa apabila Debt to Equity Ratio (DER) mengalami peningkatan maka kemampuan perusahaan untuk mendapatkan profitabilitas akan menurun.

\section{Pengaruh Debt to Equity Ratio (DER) terhadap Good Corporate Governance (GCG)}

Berdasarkan hasil perhitungan dengan Analisis Regresi Berganda menunjukkan bahwa Debt to Equity Ratio (DER) berpengaruh positif signifikan terhadap Good Corporate Governance $(G C G)$ pada perusahaan manufaktur sector makanan dan minuman yang terdaftar di Bursa Efek Indonesia tahun 2016 sampai dengan tahun 2018. Pengaruh yang positif tapi tidak signifikan ini menunjukkan bahwa keputusan pengambilan pendanaan atau modal suatu perusahaan akan meningkatkan system manajemen perusahaan menjadi lebih kompleks.

\section{Pengaruh Debt to Equity Ratio (DER) terhadap Price Book Value (PBV)}


Berdasarkan hasil perhitungan dengan Analisis Regresi Berganda menunjukkan bahwa Debt to Equity (DER) berpengaruh positif dan signifikan terhadap Nilai Perusahaan pada perusahaan manufaktur sector makanan dan minuman yang terdaftar di Bursa Efek Indonesia tahun 2016 sampai dengan tahun 2018.

Hasil penelitian ini menemukan bahwa adanya pengaruh positif dan signifikan terhadap nilai perusahaan, temuan ini didukung oleh trade off theory yang menyatakan bahwa (dengan asumsi titik target struktur modal yang belum optimal) peningkatan rasio utang pada stuktur modal akan meningkatkan nilai perusahaan. Hasil temuan ini juga konsisten dengan Ahmad et al (2018), Qasidah (2019) dan Dewa (2011), yang menyatakan secara parsial keputusan pendanaan berpengaruh positif dan signifikan terhadap nilai perusahaan

\section{Pengaruh Return On Asset (ROA) terhadap Nilai Perusahaan}

Berdasarkan hasil perhitungan dengan Analisis Regresi Berganda menunjukkan bahwa Return On Asset (ROA) berpengaruh positif dan signifikan terhadap Nilai Perusahaan pada perusahaan manufaktur sector makanan dan minuman yang terdaftar di Bursa Efek Indonesia tahun 2016 sampai dengan tahun 2018. Pengaruh yang positif dan signifikan ini menunjukkan bahwa Return On Asset (ROA) meningkat, maka nilai Perusahaan akan mengalami peningkatan.

Hasil penelitian ini juga menunjukan bahwa profitabilitas perusahaan manufaktur berpengaruh positif signifikan terhadap nilai perusahaan. Peningkatan pendapatan suatu perusahaan akan mendorong peningkatan yang signifikan terhadap nilai perusahaan. Kenaikan profitabiltas akan menjadikan daya tarik bagi para investor untuk menanamkan modalnya pada perusahaan, yang menyebabkan kenaikan nilai saham perusahaan tersebut, maka dengan kenaikan profitabilitas akan dapat menaikkan secara signifikan nilai perusahaan tersebut.

\section{Pengaruh Good Corporate Governance (GCG) terhadap Nilai Perusahaan (PBV)}

Berdasarkan hasil perhitungan dengan Analisis Regresi Berganda menunjukkan bahwa Good Corporate Governance (GCG) berpengaruh positif tidak signifikan terhadap Nilai Perusahaan pada perusahaan manufaktur sector makanan dan minuman yang terdaftar di Bursa Efek Indonesia tahun 2016 sampai dengan tahun 2018. Dengan kata lain dapat pula diartikan berapapun jumlah dewan komisaris independen yang mengawasi operasional perusahaan tidak akan berpengaruh terhadap nilai perusahaan.

Mekanisme good corporate governance (kepemilikan manajerial, kepemilikan institusional, komisaris independen, dan komite audit) dibutuhkan untuk menjamin dan mengawasi sistem operasional suatu perusahaan. Mekanisme GCG dapat meminimalisir terjadinya masalah perbedaan kepentingan antara principal dan agen, sehingga dapat mengurangi biaya agensi yang muncul dan menjaga hak-hak pemegang saham yang kemudian akan meningkatkan nilai perusahaan.

\section{Profitabilitas Memediasi pengaruh Struktur Modal Terhadap Nilai Perusahaan}

Berdasarkan hasil perhitungan dengan Uji Sobel menunjukkan bahwa ROA tidak dapat memediasi hubungan struktur modal dengan nilai perusahaan. Tingkat Return On Asset (ROA) yang tinggi tidak mampu memediasi pengaruh DER dengan PBV.

Hal ini diasumsikan bahwa profitabilitas yang diukur dengan pengembalian aset tidak mampu meningkatkan hubungan DER terhadap PBV. Laba yang tinggi tidak cukup mewakili pandangan Investor untuk meningkatkan nilai perusahaan. sehingga dibutuhkan indikatorindikator lain yang bisa menarik investor sehingga dapat meningkatkan hubungan DER dengan PBV. Adapun indikator-indikator Profitabilitas lain yang dapat dipakai dalam 
penelitian adalah Marjin Laba Kotor ( Gross profit Margin), Marjin Laba Bersih (Net Profit Margin) dan Return On Equity (ROE)

\section{Good Corporate Governance (GCG) memediasi pengaruh Struktur Modal Terhadap Nilai Perusahaan}

Berdasarkan hasil perhitungan dengan Uji Sobel menunjukkan bahwa GCG tidak dapat memediasi pengaruh struktur modal terhadap nilai perusahaan pada perusahaan Manfaktur sector makanan dan minuman yang terdaftar di Bursa efek Tahun 2016 - 2018.

Hal ini diasumsikan bahwa kebijakan DER itu merupakan kewenangan dari pihak manajemen perusahaan. Karena ukuran GCG menggunakan Proporsi Dewan komisaris independen maka jelas tidak relevan hubungannya dengan kewenangan manajemen perusahaan, dengan demikian sangatlah tepat jika GCG tidak atau belum memediasi hubungan tidak langsung antara DER terhadap nilai perusahaan. Para investor tidak akan mudah begitu saja untuk percaya penuh terhadap dewan komisaris independent yang dijadikan indikator untuk menilai tatakelola perusahaan yang baik. Ada beberapa indikator lain dari GCG yang bisa dipakai untuk indicator penelitian diantaranya kepemilikan manajerial, kepemilikan institusional, dan komite audit.

\section{Kesimpulan Dan Saran \\ Kesimpulan}

1. Debt to Equity (DER) berpengaruh negatif dan signifikan terhadap Return On Asset (ROA).

2. Debt to Equity Ratio (DER) berpengaruh Positif Dan signifikan terhadap Good Corporate Governance (GCG).

3. Debt to Equity Ratio (DER) berpengaruh positif dan signifikan terhadap Nilai Perusahaan.

4. Return On Asset (ROA) berpengaruh positif dan signifikan terhadap Nilai Perusahaan

5. Good Corporate Governance (GCG) berpengaruh positif tidak signifikan terhadap Nilai Perusahaan.

6. Return On Asset (ROA) tidak dapat memediasi hubungan struktur modal dengan nilai perusahaan.

7. GCG tidak dapat memediasi hubungan struktur modal terhadap nilai perusahaan.

\section{Saran}

1. Penelitian ini hanya menggunakan sampel perusahaan yang khusus bergerak dibidang makanan dan minuman dan sampel yang diambil pun hanya perusahaan yang tiga tahun secara berturut-turut menerbitkan laporan keuangan tahunan, maka disarankan untuk peneliti selanjutnya agar melakukan penelitian dengan sampel yang lebih beragam.

2. Penelitian ini menggunakan dua variabel intervening dan satu variabel independen maka untuk penelitian selanjutnya agar menmbah atau mencoba meneliti variabel intervening dan independen dengan variabel lain yang mungkin memiliki pengaruh missal seperti Growth ataupun Corporate Social Responsibilty dan lainnya.

\section{Daftar Pustaka}

Ahmad, et al. 2018. "Peran Profitabilitas Dan Good Corporate Governance Dalam Memediasi Pengaruh Struktur Modal Dan Pertumbuhan Perusahaan Terhadap Nilai Perusahaan Studi Empris Perusahaan Property Dan Real Estate Di Bursa Efek Indonesia Tahun 2013-2016”. Jurnal Ilmiah Ekonomi. STIE Dharma Putra Semarang. 
Ahmad, Sahri. 2016. “Analisis Pengaruh Kinerja Keuangan Dengan Corporate Social Responsibility dan Good Corporate Governance Sebagai Variabel Moderating”. Skripsi. STIE Pelita Nusantara Semarang

Dewa, Kadek Oka Kusumajaya. 2011. "Pengaruh Struktur Modal dan Pertumbuhan Perusahaan Terhadap Profitabilitas dan Nilai Perusahaan Pada Perusahaan Manufaktur di Bursa Efek Indonesia Tahun 2006-2009”. Jurnal Ekonomi. Universitas Udayana Denpasar.

Eli, Safrida. 2008. "Pengaruh Struktur Modal dan Pertumbuhan Perusahaan Terhadap Nilai Perusahaan Pada Perusahaan Manufaktur Di Bursa Efek Jakarta”. Jurnal Ekonomi. Universitas Sumatra Utara Medan.

Eni, et al. 2014. "Pengaruh Kinerja Keuangan Terhadap Nilai Perusahaan dengan Pengungkapan Corporate Social Responcibility dan Good Corporate Governance Sebagai Variabel Pemoderasi (Studi Kasus Di Bursa Efek Indonesia Periode 2010-2012)". E-Journal S1 Ak Universitas Pendidikan Ganesha Jurusan Akuntansi S1. Volume 2 No. 1

Ghozali, Imam. 2011. Aplikasi Analisis Multivariate dengan Program SPSS. Semarang: Badan Penerbit Universitas Diponegoro.

http://www.statistikolahdata.com/2017/01/uji-mediasi-dengan-sobel-test.html

http://quantpsy.org/sobel/sobel.htm

I Gusti Ayu Agung, Kirana Windu Bulan dan Badjra, Ida Bagus. 2018. " Peranan Profitabilitas Dalam Memediasi Pengaruh Struktur Modal Terhadap Nilai Perusahaan Di BEI Periode 2013-2017”. E-Jurnal Manajemen Unud, Vol.-, No.-

Kadek, Apriada dan Made Sadha, Suardhika. 2016. "Pengaruh Struktur Kepemilikan Saham, Struktur Modal dan Profitabilitas Pada Nilai Perusahaan”. E-Jurnal Ekonomi dan Bisnis Universitas Udayana 5.2. Fakultas Ekonomi dan Bisnis Universitas Udayana Bali.

Mahatma Dewi, Ayu sri dan Wirajaya, Ary. 2013. "Pengaruh Struktur Modal, Profitabilitas Dan Ukuran Perusahaan Pada Nilai Perusahaan”. E-Jurnal Akuntansi. Universitas Udayana.

Natalia, et al. 2018. "The Effect of Good Corporate Governance on Company Value in Life Company Cycle". Research Journal of Finance and Accounting Vol. 9 No. 20. Economics and Business Faculty, Udayana University, Denpasar.

Nonih, Sukriyowati. 2016. "Pengaruh Struktur Modal Dan Pertumbuhan Perusahaan Terhadap Nilai Perusahaan Dengan Good Corporate Governance Sebagai Variabel Moderating". Jurnal Akuntansi Manajerial Vol. 1. Fakultas Ekonomi dan Bisnis Universitas 17 Agustus 1945 Jakarta.

Nur, Mufidah dan Puji Endah, Purnamasari. 2018. "Pengaruh Profitabilitas Terhadap Nilai Perusahaan Dengan Pengungkapan Corporate Social Responsibility Dan Good Corporate Governance Sebagai Variabel Moderating”. Jurnal Keuangan dan Perbankan Syariah Volume 6. Universitas Islam Negeri Maulana Malik Ibrahim Malang.

Purwita Sari, Elisa. 2013. “Analisis Pengaruh Struktur Modal Terhadap Profitabilitas Studi Empiris pada Perusahaan Manufaktur yang Terdaftar di Bursa Efek Indonesia Tahun 2009 - 2011. Skripsi. Fakultas Ekonomika Dan Bisnis. Universitas Diponegoro Semarang.

Reny Dyah, Retno M. 2012. "Pengaruh Good Corporate Governance dan Pengungkapan Corporate Social Responsibility Terhadap Nilai Perusahaan. Jurnal Nominal. Vol. 1 .

Shaw, K. W. 2003. "Corporate Disclosure Quality, Earning Smoothing and Earning's Timeliness". Journal of Business Research. Pp. 1043-1050. 
Sugeng, Bambang. 2009. "Pengaruh Pertumbuhan Perusahaan dan Struktur Modal Terhadap Good Corporate Governance". Jurnal Ekonomi Bisnis. Vol. 6. Pp. 6.

Suharli, Michell. 2006. "Faktor-Faktor yang Mempengaruhi Nilai Perusahaan pada Perusahaan Go Public di Indonesia". Jurnal Manajemen Akuntansi. Vol. 6. Pp. 1.

Ta'dir, et al. 2014. "Struktur Modal, Ukuran Perusahaan Dan Risiko Perusahaan Terhadap Nilai Perusahaan Otomotif Yang Terdaftar di BEI". Jurnal EMBA Vol. 2 No. 2. Universitas Sam Ratulangi Manado.

Triasesiarta, Nur. 2018. "Pengaruh Growth Opportunity, Profitabilitas Dan Struktur Modal Terhadap Nilai Perusahaan Dengan Dividen Sebagai Variabel Intervening Pada Perusahaan Manufaktur Yang Terdaftar Di BEI Pada Periode 2014-2017”. Jurnal Manajemen Bisnis Indonesia Vol. 5, Nomor 3. Institut Bisnis Nusantara.

Umi Mardiyati, et al. 2012. "Pengaruh Kebijakan Dividen, Kebijakan Hutang dan Profitabilitas Terhadap Nilai Perusahaan Manufaktur Yang Terdaftar di Bursa Efek Indonesia (BEI) Periode 2005-2010". Jurnal Riset Manajemen Sains Indonesia (JRMSI) |Vol. 3, No. 1. Fakultas Ekonomi Universitas Negeri Jakarta. Undang-undang Republik Indonesia Nomor 40 Tahun 2007 tentang Perseroan Terbatas. Jakarta: Penerbit Pustaka Yustisia. 